\title{
Knowledge and opinions of patients and medical staff about patients' rights
}

\author{
Mariola Czajkowska®, Anna Janik, Katarzyna Zborowska®, Ryszard Plinta $\oplus^{\circledR}$, \\ Anna Brzek@, Violetta Skrzypulec-Plinta®i
}

Women's Health Chair, School of Health Science, Medical University of Silesia, Poland

\begin{abstract}
Objectives: The awareness of patients' rights among medical personnel and patients themselves, together with their opinions concerning these rights, is a challenging issue for health professionals. Patients' rights are very specific legal regulations that have been drafted to protect patients' dignity and autonomy. The main objective of this research was to assess the knowledge of patients' rights among medical personnel of health care institutions and among patients themselves. Specific objectives were also adopted, such as: assessment of the impact of the mode of hospital admissions on the knowledge of patients' rights, analysis of factors influencing the knowledge of patients' rights and the analysis of sources of knowledge concerning patients' rights.

Material and methods: The study was conducted among two groups: patients and medical personnel. A group of 618 patients (including 411 women and 207 men) and 901 medical professionals (doctors, nurses, midwives) was examined via a questionnaire designed to verify their knowledge of patients' rights and to collect their opinions on the applicable laws. An integral part of the questionnaire for patients was The Hospital Anxiety and Depression Scale (HADS).

Results: The research showed a high knowledge of patient's rights demonstrated by the surveyed doctors, nurses and midwives. Good knowledge of patients' rights among healthcare professionals was reflected in good level of informing patients about their rights, which correlates with their high level of awareness.

Conclusions: The following conclusions were drawn based on the research: education, seniority and profession determine the knowledge and respecting patients' rights, the mode of admission to hospital is a factor determining the knowledge of applicable patients' rights, medical staff's lack of knowledge about existing patients' rights has a significant impact on exercising these rights or their violation.
\end{abstract}

Key words: right; patient; patients' rights

Ginekologia Polska 2021; 92, 7: 491-497

\section{INTRODUCTION}

Patients' rights are a specific type and integral part of human rights. They were created with the dignity and autonomy of patients in mind and are essential in today's medicine. Patients'rights are the realization of human rights in specific situations related to the use of medical services.

First discussions around patients' rights started in the $20^{\text {th }}$ century and they have been closely linked to the history of wars and human race (both soldiers and civilians). Human rights are reflected in international documents such as the Universal Declaration of Human Rights (1948), the European Convention on Human Rights and Fundamental Freedoms (1950), the European Social Charter (1961) and the
International Covenant on Civil and Political Rights (1966). The need to define patients' rights was forced by the processes taking place in medicine, the development of medical sciences and technologies and the sense of threat to human rights and dignity in the process of medical treatment. These rights are supposed to protect patients from abuses in diagnostics and medical treatment as well as improper application of biological and medical achievements (medical experiments). The public debate on patients' rights was caused by two events in medicine of the 60s: the disclosure of research for scientific purposes carried out on patients without their consent (often on minors, the disabled and terminally ill), which took place in the US in 1966,

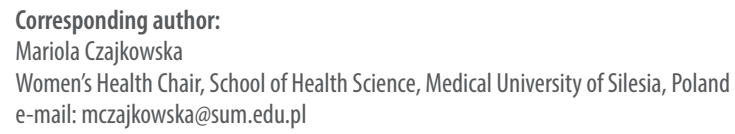


and the first heart transplantation carried out by Professor Christian Barnard in Cape Town in 1967. These events have caused many disputes, questions and doubts of an ethical, philosophical and legal nature. That is how the process of creating new deontological standards by the World Medical Associations has begun [1].

Due to the development of new communication technologies and the internet in particular, it is important that patients' knowledge is reliable and fully understood by them. Only verification can show whether they are known and observed by both parties.

The main objective of this research was to assess the knowledge of patients' rights among medical personnel of health care institutions and among patients them- selves. Specific objectives were also adopted, such as the assessment of the impact of the mode of hospital admissions on the knowledge of patients' rights, analysis of factors influencing the knowledge of patients' rights and the analysis of sources of knowledge concerning patients' rights.

\section{MATERIAL AND METHODS}

\section{Study population}

The prospective study covered a group of medical workers - 901 persons, including 200 doctors, 493 nurses and 208 midwives (Tab. 1, Fig. 1 and 2) and a group of 618 patients, including 411 women and 207 men (Tab. 2). The following inclusion criteria were adopted for the medical staff: medical profession regardless of the basis of employ-

\section{Table 1. Medical staff's job seniority in years}

\begin{tabular}{|l|c|c|c|c|}
\hline Statistical parameter & Doctors & Nurses & Midwives & Kruskal-Wallis test \\
\hline Number & 175 & 406 & 162 & $p=0.0001$ \\
\hline Mean & 13.4 & 24.7 & 14.1 & \\
\hline Standard deviation & 9.5 & 9.3 & 9.8 \\
\hline Lower quartile & 5.0 & 20.0 & 6.0 & \\
\hline Median & 12.0 & 26.0 & 12.0 & 21.8 \\
\hline Upper quartile & 20.0 & 31.0 & $p<0.000001$ & \\
\hline Test of normality & $p<0.000001$ & $p<0.000001$ & & \\
\hline
\end{tabular}

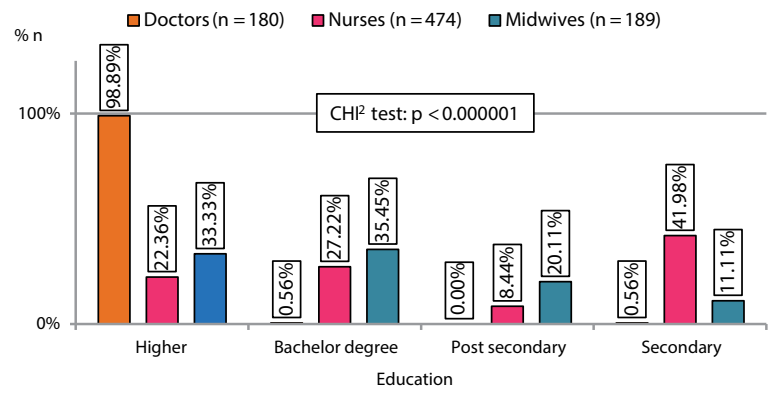

Figure 1. Education of the study group (medical personnel)

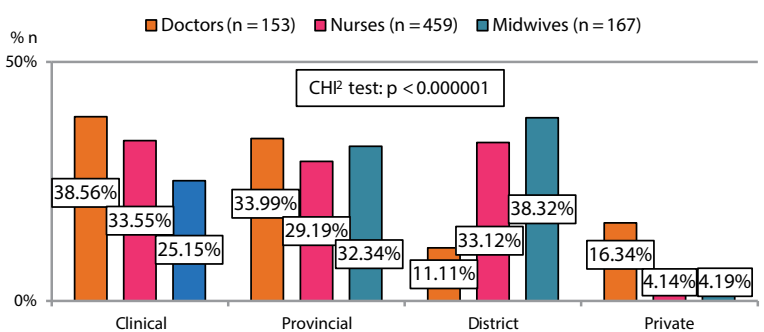

Place of work - hospital

Figure 2. Workplace of the study group (medical personnel)

\begin{tabular}{|l|c|c|c|}
\hline Table 2. Age in the study group — patients (women and men) & \multicolumn{2}{l|}{ Mann-Whitney's } \\
U TEST
\end{tabular}


ment; consent to participate in the survey and fully completed questionnaire. For the group of the surveyed patients the criteria for inclusion in the survey were: admission to the hospital for treatment or diagnosis; informed consent of the patient to conduct the survey and fully completed questionnaire.

The research was carried out in the period from 2 January 2017 to 30 December 2017 in hospitals of the Silesian Province. It was conducted after obtaining the consent of the directors of the units concerned.

\section{Research methods}

The research tool was a questionnaire developed by the authors of this study, which included open and closed questions concerning patients and medical staff's knowledge and opinions about patients' rights as in the Act of 6 November 2008 on Patients' Rights and Ombudsman of Patients' rights (Journal of Laws, 2009 no. 52 poz. 417).

The anonymous research questionnaire for medical personnel consisted of the following parts: a general interview (containing twenty-five questions, including three multiple-choice questions), and a sociometric interview containing questions about occupation, seniority, education, specialization, the hospital where the subject currently works, the ward and attitude towards religion.

The anonymous research questionnaire for patients included a general interview containing twenty-four closed questions, including three multiple-choice questions. The questions aimed to collect respondents' subjective evaluation of their level of knowledge about patients' rights and their opinions concerning these. It also collected sociometric data such as age, gender, place of residence, education, professional status, hospital where the patient was currently staying, total number of stays in the hospital, mode of admission to the hospital (emergency, referral) and attitude towards religion.

An integral part of the questionnaire for patients was The Hospital Anxiety and Depression Scale (HADS) by A. S. Zigmond and R. Snaith. The HADS scale is the most used tool developed for the study of non-psychiatric patients between the age of 16-65 years, with HADS measuring the condition rather than the trait. The scale consists of two independent subscales measuring anxiety and depression levels. Each of them contains seven statements concerning the current condition of the tested subject, which can be assessed in a range of 0 to 3 points.

The points obtained were counted separately for anxiety and depression. Scores of up to 7 points in each of the subscale indicate the norm, scores between 8 and 10 points are a borderline score for moderate anxiety/depression symptoms, while scores 11 and above indicate the pathological level of anxiety/depression.
For statistical analysis of the surveys Excel 2001 and STATISTICA 10 were used. $P<0.05$ was assumed as the level of statistical significance. The following tests were used in statistical research: Shapiro-Wilk normality test, Mann-Whitney's U test, Kruskal-Wallis test, Yates's chi-squared test and the exact Fisher test.

\section{Ethical statement}

All subjects gave their informed consent for inclusion before they participated in the study. The study was conducted in accordance with the Declaration of Helsinki, and the protocol was approved by the Ethics Committee of the Medical University of Silesia (KNW/0022/KB/212/15).

\section{RESULTS}

The research showed a high knowledge of patient's rights demonstrated by the surveyed doctors, nurses and midwives (Fig. 3). The question concerning knowledge of particular regulations was answered by all respondents. Statistical significance has been obtained for four domains: patients' right to health services $(p<0.000001)$, patients' right to respect for dignity and intimacy $(p<0.000001)$, patients' right to store valuables in deposit $(p<0.000001)$ and patients' right to pastoral care $(p<0.000001)$ (Tab. 3$)$.

Participants of the study (medical personnel in the vast majority of cases) indicated medical publications, participation in conferences and symposiums as the main source of knowledge on patients' rights. They also emphasized the fact that they gained knowledge in medical schools. Good knowledge of patients' rights among healthcare professionals was reflected in good level of informing patients about their rights (Fig. 4), which correlates with their high level of awareness (Fig. 5).

Despite knowing and respecting patients' rights, respondents indicated that they witnessed situations where patients' rights were violated. These were mainly the cases of the lack of respect for dignity, lack of reliable information about the health condition/surgical procedures performed and discussing patients' health condition/carrying out inter-

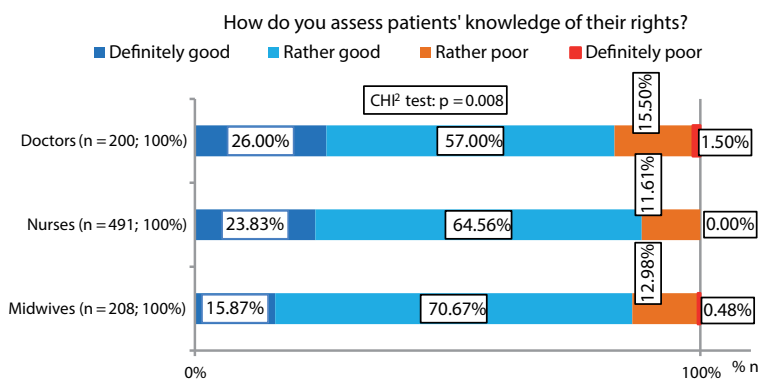

Figure 3. State of knowledge on the applicable patient rights (medical personnel) 
Table 3. Knowledge of elements of patient rights by medical personnel

Element of law

The patient's right to health services

The patient's right to information

The patient's right to confidentiality

The patient's right to consent to health services

The right of the patient to respect his or her intimacy and dignity

The patient's right to access their medical records

The patient's right to respect for his or her private and family life

Patient's right to store his or her valuables in deposit

The patient's right to pastoral care

\begin{tabular}{|c|c|c|c|}
\hline $\begin{array}{c}\text { Doctors } \\
(\mathbf{n = 2 0 0})\end{array}$ & $\begin{array}{c}\text { Nurses } \\
(\mathbf{n}=\mathbf{4 9 3})\end{array}$ & $\begin{array}{c}\text { Midwives } \\
(\mathbf{n}=\mathbf{2 0 8})\end{array}$ & $\mathbf{C H I}^{2}$ test \\
\hline $85.00 \%$ & $94.52 \%$ & $80.77 \%$ & $\mathrm{p}<0.000001$ \\
\hline $95.00 \%$ & $97.57 \%$ & $96.15 \%$ & $\mathrm{NS}(\mathrm{p}=0.19)$ \\
\hline $94.00 \%$ & $95.13 \%$ & $91.83 \%$ & $\mathrm{NS}(\mathrm{p}=0.22)$ \\
\hline $91.50 \%$ & $95.13 \%$ & $92.31 \%$ & $\mathrm{NS}(\mathrm{p}=0.12)$ \\
\hline $92.50 \%$ & $99.80 \%$ & $96.15 \%$ & $\mathrm{p}<0.000001$ \\
\hline $93.50 \%$ & $95.54 \%$ & $94.23 \%$ & $\mathrm{NS}(\mathrm{p}=0.47)$ \\
\hline $83.00 \%$ & $87.83 \%$ & $88.46 \%$ & $\mathrm{NS}(\mathrm{p}=0.17)$ \\
\hline $83.50 \%$ & $94.52 \%$ & $64.90 \%$ & $\mathrm{p}<0.000001$ \\
\hline $71.00 \%$ & $96.15 \%$ & $91.83 \%$ & $\mathrm{p}<0.000001$ \\
\hline
\end{tabular}

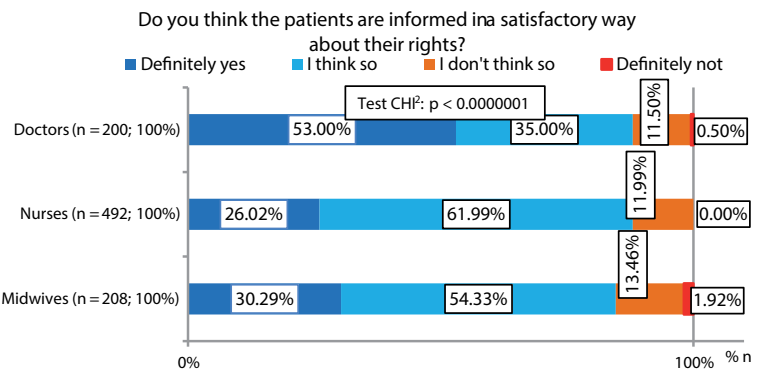

Figure 4. The level of informing patients about their rights (medical personnel)

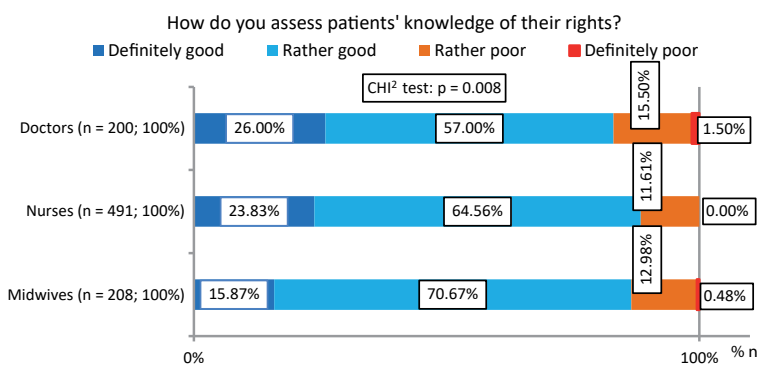

Figure 5. Patients' knowledge of their rights

\begin{tabular}{|c|c|c|c|c|}
\hline Violated patients' right & $\begin{array}{l}\text { Doctors } \\
(\mathrm{n}=36)\end{array}$ & $\begin{array}{l}\text { Nurses } \\
(n=26)\end{array}$ & $\begin{array}{c}\text { Midwives } \\
(\mathrm{n}=\mathbf{8 3})\end{array}$ & $\mathrm{CHI}^{2}$ test \\
\hline No respect for patient intimacy & $33.33 \%$ & $100.00 \%$ & $19.28 \%$ & $p<0.000001$ \\
\hline Lack of reliable information on health condition/surgery & $5.56 \%$ & $26.92 \%$ & $6.02 \%$ & $p=0.005$ \\
\hline Lack of respect for the dignity of the patient / insulting him or her & $22.22 \%$ & $26.92 \%$ & $12.05 \%$ & NS $(p=0.13)$ \\
\hline No protection of personal data/leaving documentation in a public place & $13.89 \%$ & $15.38 \%$ & $4.82 \%$ & NS $(p=0.11)$ \\
\hline Refusal to allow a person to accompany the patient when providing information & $0.00 \%$ & $7.69 \%$ & $1.20 \%$ & NS $(p=0.11)$ \\
\hline Information given via telephone to third parties about the patient's condition & $0.00 \%$ & $7.69 \%$ & $4.82 \%$ & NS $(p=0.36)$ \\
\hline Discussing the patient's health/carrying out an interview in the presence of third parties & $2.78 \%$ & $42.31 \%$ & $10.84 \%$ & $p=0.0004$ \\
\hline Refusal of access to medical records/restriction of access to medical records & $2.78 \%$ & $3.85 \%$ & $3.61 \%$ & $\mathrm{NS}(p=0.95)$ \\
\hline
\end{tabular}

view in the presence of third parties (Fig. 4, Tab. 4). They also indicated situations in which it is possible to limit the rights of patients such as safety/health/life threat $(p=0.0003)$, epidemic threat $(p=0.001)$, incapacitated patient $(p=0.03)$, in order to save life $(p=0.02)$, direct coercion $(p=0.03)$ with the individual right to refuse certain health services resulting from one's religious beliefs.

A similar analysis was carried out among patients in order to verify the respect of patients' rights by health care professionals and the knowledge of these rights by patients themselves.

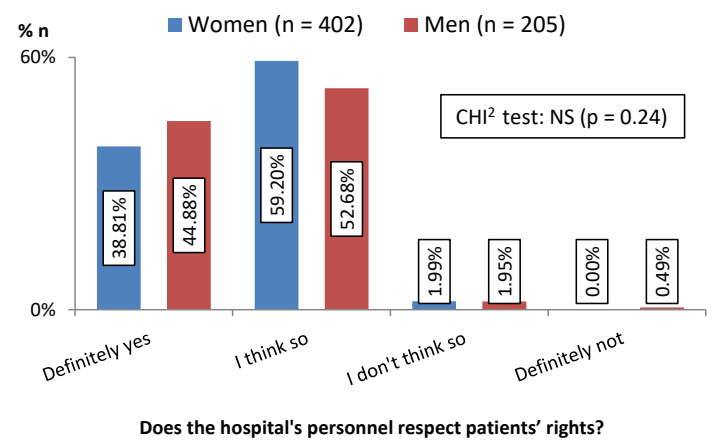

Figure 6. Respect for patient rights during current hospitalization 
More than half of the respondents (84.92\% of women and $80.93 \%$ of men) were admitted to hospital on a scheduled referral basis, the remaining patients on an emergency basis due to their current clinical state.

The group of the surveyed patients, both women and men, had satisfactory knowledge of the existing patients' rights in Poland. $97.09 \%$ of women and $94.69 \%$ of men claimed to have a good knowledge of these. When asked about the sources of their knowledge, $50 \%$ of women and $58.21 \%$ of men claimed it was the knowledge collected during previous hospitalizations.

It has been shown that during the current treatment/diagnostic process, about $30 \%$ of respondents, both men and women, were not informed about their rights. The remaining patients claimed they were informed about their patients' rights in full detail according to the Act in force.

The participating patients, both men and women, claimed that the hospital where they were currently staying was almost $100 \%$ compliant with the patients'rights (Fig. 6).

Despite knowing and respecting patients' rights the surveyed patients also witnessed the situations in which these rights were violated (e.g., right to respect for intimacy and dignity, about $50 \%$ ), however the violation of the law did not concern the respondents themselves. The same domain was indicated by healthcare professionals.

An integral part of the questionnaire for patients was The Hospital Anxiety and Depression Scale (HADS). In this study, $61.44 \%$ of female subjects and $49.20 \%$ of male subjects (out of 376 women and 187 men) did not show any depressive disorders. The borderline was observed in $24.47 \%$ of women and $28.88 \%$ of men. Depressive disorders were diagnosed in $14.10 \%$ of women and $21.93 \%$ of men. The diagnosis of occurring anxiety disorders significantly correlates with the analytical assessment of both the knowledge of the patient's existing rights and the subjective evaluation of medical situations in which the patient's rights are not respected.

\section{DISCUSSION}

The medical staff and patients'knowledge and opinions on the patient's rights in force in Poland are inseparably connected with the quality of provided health services and thus patient safety. Health care services, due to their specific nature, are not just about guaranteeing the patient a specific health result or a complete cure. Professional medical personnel need to ensure that health services are provided with due care and in accordance with current medical knowledge, with respect and knowledge of the law to ensure patient safety.

The research showed a significant increase in patients' knowledge of their rights. The research carried out on a group of 618 patients showed unequivocally that the knowledge of patients' rights in force has significantly improved. The data also suggest that those taking part in the research are familiar with particular provisions of the Act on Patient's Rights, and this knowledge was obtained from medical staff (doctor, nurse, midwife). Similar trends were observed in the research conducted in Poland by the Public Opinion Research Centre (CBOS) and Wł. Derczyński, K. Wroński and many other researchers [2-5].

There has been a significant increase in patients' awareness of their rights. The direct impact on the increase in the knowledge of patients' rights by those concerned may also result from the provisions of the Act of 27 August 2004 on health services financed from public funds (Journal of Laws of 2018, item 1510, as amended) stating that under Article 64 the therapeutic entity is obliged to display information on patients' rights in a visible place for patients (i.e., in hospital wards, emergency rooms) and it is subject to control by the National Health Fund. The factors that differentiated the level of knowledge on patients' rights in previous studies were the level of patients' education and the place of their residence.

As the main source of knowledge, medical personnel named scientific publications, and to a small extent provisions of the Act on Patient's Rights and the Ombudsman of Patients' rights and the medical school. Similar results were obtained in the studies by Olejniczak et al. and L. Wdowiak [6-8], which showed that the knowledge of patients' rights is highly unsatisfactory $[8,9]$. Foreign researchers have also shown a lack of knowledge of legal regulations concerning patients' rights among newly employed healthcare workers in Barbados. This is due to a lack of medical law, including patient rights in education programs. Insufficient education in this respect will translate into insufficient knowledge of doctors, nurses and midwives taking up employment in their professions $[9,10]$.

Different results concerning the sources of knowledge on patient's rights were obtained by the team headed by J. Gotlib. The respondents, $86 \%$ of physicians and $70 \%$ of nurses, indicated the Act on Patients'Rights and the Ombudsman of Patients' Rights as the main source of knowledge; however, their knowledge was either average or poor [9].

The study by G. Iwanowicz-Palus et al. showed that physicians' knowledge was largely dependent on their age, position and level of specialization. In the survey conducted by Iwanowicz-Palus, more than half of the nurses indicated the Charter of Patients' Rights as a source of knowledge about patient's rights (studies conducted before 2008) [9, 10]. Similar results were obtained by E. Grochans, who conducted a survey among nurses. These with higher vocational education proved to have greater knowledge about patients' rights [11]. 
It was found as a result of the conducted research that knowledge and informing patients about their rights does not correlate with patients' own evaluation. Based on the analysis of this research, it was noted that the staff highly assessed the degree of information provided to patients about their rights, which was also highly appreciated by the patients themselves. As to the essence of the violation of patients' rights by medical personnel, the research showed that the right indicated by patients was the right to respect for intimacy and dignity. Out of all patients' rights, the right to respect for dignity appears to be the most fundamental and, together with the right to life and freedom, belongs to fundamental human rights [8, 12-14]. Nursing and Midwifery Code of Ethics of the Republic of Poland, the Code of Medical Ethics and all medical acts clearly oblige medical personnel to respect the personal dignity of each patient. Respect for the right to dignity obliges medical personnel to treat patients with dignity regardless of their age, gender or education. This treatment allows the patients to make conscious decisions. The research showed that it was medical staff who witnessed the violation of this law most often. Complaints against medical personnel also concerned failure to respect the right to intimacy and dignity.

As other researchers point out, the patient's right to medical records is most often violated by medical personnel. It is manifested by the refusal to allow the patients to access their own medical documentation [15-17]. However, the analysis of this research showed that this law was not blatantly violated in case of our respondents. For the patient, access to his or her medical records is the exercise of his or her rights to information [15-20].

The right to information about one's medical condition is one of the crucial rights contained in the Act on Patients' Rights and the Ombudsman of Patients' Rights, as it is inextricably linked with the expression of informed consent to the proposed treatment, diagnostic, surgical and nursing procedures [21, 22].

In a significant percentage of patients in hospital, mental disorders such as anxiety or depression are observed. There is a discussion around the co-occurrence of depression and chronic diseases, while less research has been done into anxiety, even though it is one of the most common emotional responses to the disease [21-26]. This research showed that the level of anxiety was statistically significantly higher than that of depression, but it should be noted that the level of both anxiety and depression was significantly higher in men, independent of the age of the respondents.

The presented results of this research indicate the need provide ethical education including the knowledge about the patient's rights, in particular the right to dignity and intimacy as well as the right to information, health services and medical records.

\section{CONCLUSIONS}

Education, occupation and employee's seniority are important determinants of knowledge and respect for patient's rights. Patients' mode of admission to the hospital is a modifier that determines the knowledge of their current rights. Lack of knowledge of the applicable patient's rights by the staff has a significant impact on the exercise or non-observance of patients' rights.

\section{Conflicts of interest}

No competing financial interests exist. The authors report no financial, personal, political, intellectual or religious conflicts of interest. The authors alone are responsible for the content and writing of the paper.

\section{REFERENCES}

1. Łaska-Formejster A. Pacjent w sieci zależności. Społeczny kontekst praw i autonomii pacjenta. 2015, doi: 10.18778/7969-815-8.

2. Karkowska D. Ustawa o prawach pacjenta i Rzeczniku Praw Pacjenta komentarz. 3 wydanie Wolters Kluwer Warszawa 2016: s 571,586; 275: 215.

3. Rudawska I. Jakość relacji pacjent profesjonalista w sektorze usług medycznych. 2005; 3: 181-182.

4. Derczyński Wł., Wiedza o prawach pacjenta. Komunikat CBOSWarszawa. 2001.

5. Wroński K. Znajomość praw pacjenta przez osoby leczone w Klinice Chirurgii Onkologicznej Uniwersytetu Medycznego w Łodzi. Onkologia Polska. 2007; 10(2): 75-83.

6. Olejniczak M, Michałowska M, Basińska K. Opinie studentów Gdańskiego Uniwersytety ycznego na temat przestrzegania praw pacjenta w czasie odbywania zajęć klinicznych. Ann Acad Med Gedan 2011; 41; 79: 87.

7. Walrond ER, Jonnalagadda R, Hariharan S, et al. Knowledge, attitudes and practice of medical students at the Cave Hill Campus in relation to ethics and law in healthcare. West Indian Med J. 2006; 55(1): 42-47, doi: 10.1590/s0043-31442006000100010, indexed in Pubmed: 16755819.

8. Wdowiak $L$, et al. Prawa pacjenta w programach edukacyjnych uczelni medycznej. ZdrowiePubliczne. 2004; 114(405): 411.

9. Gotlib J, Dykowska G, et al. Ocena wiedzy i postaw personelu medycznego Samodzielnego Publicznego Szpitala Klinicznego im. Prof. Orłowskiego w Warszawie wobec praw pacjenta. Annales Academia Medicae Silesinsis. 2014; 68: 91-92.

10. Iwanowicz-Palus G., Znajomość praw pacjenta 2002; 112: s. 320-325.

11. Grochans E, Głowacka T, Szkup-Ja, et al. Zaremba-Pechmann L., Rotter I., Karakierwicz B., Wpływ poziomu wykształcenia pielęgniarek na znajomość wybranych aktów prawnych wykorzystywanych w pielęgniarstwie, Problemy Pielęgniarstwa. 2001; 19: s. 463-467.

12. Ruth $\mathrm{E}$, John Ce. g. Whilliams. Różnice w postawach etycznych pielęgniarek i studentów medycyny. EtykaPielęgniarstwa. 2003; 10: 149-164.

13. Powszechna Deklaracja Praw Człowieka [ Dokument elektroniczny]. http:// www. Unesco.pl/fileadmin/user_upload/pdf/ (29.01.2019).

14. Tałaj A, Suchorzewska J, et al. Postawy pielęgniarek i położnych wobec osób chorych i cierpiących w aspekcie obowiązujących norm prawnych i moralnych. Problemy Pielęgniarstwa. 2007; 15(32): 33.

15. Kryska S, Rej-Kietla A. Kształtowanie się wiedzy lekarzy oraz studentów ostatnich lat medycyny w zakresie prawa pacjenta do poufności informacji. RocznikAdministracjiiPrawa. 2014; 2: 271-280.

16. Konarska P. Prawa Pacjenta ze szczególnym uwzględnieniem prawa pacjenta do dokumentacji medycznej. Polski Rocznik Praw Człowieka i Prawa Humanitarnego. UniwersytetWarmińsko-Mazurski w Olsztynie. 2016;356-357.

17. Biuro Rzecznika Praw Pacjenta, Najczęstsze skargi pacjentów, III Forum marketingu i PR w ochronie zdrowia, Warszawa 2012, s. 10.

18. Woś J. Prawa pacjenta w Polce. Geneza praw pacjenta. Podtawowe informacje. Materiały z warztatu, AkademiaPacjenta", Warzawa. 2008 r s. 8. 
19. Karkowska D. Komentarz do art.24, art. 25 ustawy o prawach pacjenta i Rzeczniku Praw Pacjenta, LEX nr. 1205593.

20. Mikos M. Bezpieczeństwo pacjenta. Z i Z Centrum Edukacji. Kraków. 2017: 13-14.

21. Ustawa z dnia 6 czerwca 1997 roku -Kodeks Karny Dz.U. 1997 nr 88 poz. 553.

22. Wroński K, Okraszewski J, et al. Artykuł 192 Kodeksu Karnego. Nowotwory. Journal of Oncology. 2008; 1: 82-85.

23. Mener M, et al. Dore I. Cloutier AM, Chronic physical comorbidity burden and the quality of depression treatment in pirmarycare:A systematic review. JPsychosom Res. 2015; Jan.
24. Egede LE. Major depression in indyviduals with chronic medical disordes: prevelence, correlates and association with health resource utilization, los productivityand functional disability. Gen Hosp Psychiatry 2007; 29: 409-416.

25. Nowicka-Sauer K, Pietrzykowska M, et al. Lęk u pacjentów z chorobami przewlekłymi: istotny, a marginalizowany problem. Famili Medicine \& Primary Care Review. 2015; 17(2): 120-123.

26. Skorupska-Król A, Samborska A, Bodys-Cupak I, et al. Wiedza pielęgniarek na temat praw pacjenta. PolskiPrzeglądNauk o Zdrowiu. 2014; 3(40): 193-199. 